\title{
The Monitoring of selected sources in the administration of the Forests of Brno
}

\author{
Jana Marková1, ${ }^{1}$, Petr Pelikán ${ }^{1}$, and Miloslav Šlezingr ${ }^{1}$ \\ ${ }^{1}$ Department of Landscape Management, Mendel University in Brno, Zemědělská 3, 61300 Brno, \\ Czech Rep.
}

\begin{abstract}
The article concerns the monitoring of selected sources (monitored a total of 10 springs, presented the results of 5 springs) administered by the Forests of the city of Brno in the northern district of Brno-county, describing their current state, including the evaluation of selected water quality parameters. The basis of the study was to measure basic water quality parameters (water temperature, $\mathrm{pH}$, oxygen and measuring the rate of flow of water in springs) and sampling for laboratory analysis. The values obtained were tabulated and graphically evaluated and compared with values in accordance with Decree no. 252/2004 Coll., which lay down the hygienic requirements for drinking water. Based on the measured values charts and graphs were compiled, and the water quality of the individual strands were assessed. The overall condition of wells and their surroundings is described in detail and assessed.
\end{abstract}

\section{Introduction}

The stranded seepage of groundwater, spring or fountain, is a valuable source of drinking water. The water on our planet is one of the most important conditions for life. After all, the human body is made up of only $70 \%$ water, and plants up to $90 \%$. The average daily water consumption per capita is about 100 liters.

The importance of springs nowadays is a rather more important or frequently visited location attractive to tourists. The traveller does not know the quality of drinking water simply by looking at it. Drinking water may seem opaque, and vice versa, crystal clear drinking water does not have to be. Their quality is affected by many factors - geology, farming in the area, rainfall, both their quantity and quality. The location of wells in the relevant scientific soil and geological conditions has an impact on not only the infiltration of rainwater, thus subsidizing its source and its properties. These problems concern, eg. [1]. Springs natural seep from the groundwater to the surface [2]. Fountains are then objects in which the sources are concentrated in one place. Respect for springs and fountains has a long history. The first wells were built in the first half of the 20th century as a source of drinking water for farmers and foresters. In the second half of the 20th century, devastation occurred and some disappeared due to ameliorative interventions and the influence of unfriendly human intervention.

\footnotetext{
*Corresponding author: jana.markova@mendelu.cz
} 
A fountain is a discharge spring, which rises from the ground, often modified for a building. The largest building boom for wells in our country was in the first quarter of the 20 th century.

Anthropogenic influences on the quality of the water wells often eliminate filtration from the rock environment, then it also influences the concentration of minerals. Springs are often not significantly contaminated by anthropogenic pollution. In the last few years phosphorus is particularly a problem in surface waters, as stated in [3], who monitor the concentration of phosphorus to flow in the vicinity of the site which is the subject of our article. Similar concentrations of pollutants in the flow for minimum flow rates [4].

\section{Materials and methods}

The selected monitored wells, the parameters of which are presented here, are administered by the Lesy města Brna, a.s.. Ten wells were selected for monitoring and regular measurement in cooperation with Lesy města Brna. The fountains are located north of Brno. The results of measurements on five wells are presented in this article. The following wells are presenteds:

U Sovy spring, U Širokého proudu spring, V Hájku spring, Olšová spring, and Brčálka spring.

Measurement and fieldwork were done from April 2014 to March 2015. In the first phase, it was done in cooperation with the Lesy města Brna, a.s., (in the report, the wells are located) who know of specific resources for monitoring. The employees of the company conducted an initial reconnaissance of the springs and their surroundings. Key data were obtained through field measurement, observation and evaluation of sources of laboratory analyses of water from various sources.

Measurements were carried out each month from May 2014 to March 2015. It was measured for $\mathrm{pH}$, water temperature and oxygen saturation, and the Multi 340i. Further, the air temperature was recorded. Measurement spring yields were directly measuree, and water flowing from a spring was captured in a container - graduated cylinder of 11 . For sources with lower yields, then a graduated cylinder of $500 \mathrm{ml}$ or $250 \mathrm{ml}$.

In October 2014 and February 2015, water samples were taken for laboratory testing for water quality. Samples were processed in a laboratory at Brněnské vodovody a kanalizace. Water quality was assessed according to Department of Agriculture decree no. 252/2004 Coll., which lays down the hygienic requirements for drinking water, warm water and the frequency and scope of drinking water control. Water from springs were subjected to microbiological analysis and physico-chemical analysis, and the following pareamers were provided: $\mathrm{pH}$, conductivity, alkalinity, chloride, ammonium, nitrate, nitrite, chemical oxygen permanganate, turbidity, color, calcium, magnesium, iron, colonies of Coliform Bacteria, between $36^{\circ}$ and $22^{\circ} \mathrm{C}$. The frequency and scope of the laboratory analysis was done according to a manager and sponsor (Lesy města Brna).

\section{Results}

\subsection{Location and description of the current status of wells}

The mapped spring is located on land designated for forestry, and there was a technological modification. Four wells are in good condition. The V Hájku spring is in a worse state. Mapped wells located in the South Moravian Region district Brno-venkov. 


\section{Brčálka Spring}

Localization - City: Lelekovice; GPS coordinates: 49²17'51.00" N, 16³4'59.88" E; Altitude: $368 \mathrm{~m} \mathrm{n}$. m Brčálka spring is located in the northern part of the village of Lelekovice. It is located in the Ponávka river basin.

This is probably the underpinning of shallow flow spring. This natural fountain is often used by people from the neighborhood. The entire structure is made of natural quarry stone, on which there is a spout. The front of the well is covered with a stone wall on cement mortar. Water flows downstream from a steel pipe and into the floor, which is reinforced with stone. Water then flows from the right side of the notch path. A granite desk sits above the drain pipe on which there is the inscription: Brčálka - this fountain for thirsty wayfarers resumed in 2006, of the Strana Zelených. A trumpet revives hemispherical colonies of red algae, along with diatoms genus Achnanthes [5].

\section{Olšová spring}

Localization - City: Lelekovice; GPS coordinates: 49¹8'16.92" N, 16³4'55.86" E; Altitude: $430 \mathrm{~m} \mathrm{n}$. $\mathrm{m}$. Alder spring is located north of the village of Lelekovice approximately 800 meters from the village.

The fountain was built in the late 1980. This very volatile spring flows throughout the year. The flow will increase and multiply after more rain. Instability Flow warns against using the water without boiling it. The content of dissolved solids and conductivity varies depending on the strength of the source [5].

This spring also belongs to the Ponávka River basin. Through regular monthly monitoring we can say that it is a spring with unsteady flow throughout the year. The environment around the well is clean and tidy. There is significant waterlogging. Water flows freely into the stream culvert. At the spring there is an information board that informs visitors about the history and natural surroundings.

\section{Hájku Spring}

Localization - City: Lažánky, Holasice ; GPS coordinates: 49¹7'21.42" N , 16²4'27.54" E; Altitude: $302 \mathrm{~m} \mathrm{n}$. m. The V Hájeku Spring is located north of Holasice in the forest section titled Hajek. The yellow tourist trail passes near the well. The fountain is located approximately $1.2 \mathrm{~km}$ from Holasice.

There has never been further information on this well, and the spring is not registered in the National Register of springs and wells. The survey site wells cannot be considered as a source collecter. There is a combined construction to the wells - wood and sheet metal. The biggest problem of this location is its permanent waterlogging. The water drain from the well, is not focused. Water freely runs around the well. In the summer, the nearby spring is significantly covered by weeds and some invasive plant species. The spring coverage is volatile during the year. The spring is not very aesthetically pleasing, although it is located near marked tourist trails. The surroundings of the well are unpleasant; rubbish was even found in the summer.

\section{U Sovy Spring}

Localization - City: Lažánky ; GPS coordinates: 49¹8'10.08' N ' , 16²3'30.84" E; Altitude: $297 \mathrm{~m} \mathrm{n}$. m. The U Sovy spring is located near the forest path from Pejškov to Heroltice. This fountain was built by Lesy města Brna, a.s., in 2008 and was named after the architect Mr. Sova.

The spring is located on a slope about 30 meters from the well. Of the three slope springs is ducted pipe into the well. It is a fairly large stone masonry structure. In a niche is a statue of an owl. The outlet tube is set into the design, approximately $30 \mathrm{~cm}$ above the 
ground. Benches for tourists to rest on are built around the whole structure of the. It is very beautiful and clean in or near the water spring. There are also information boards describing the Deblín Forest Administration. The building is very nice. The spring showed yield volatility during the year.

\section{U Širokého proudu Spring}

Localization - City: Sentice; GPS coordinates: 49¹7'56.47" N , 16²5'03.30" E ; Antitude: $285 \mathrm{~m} \mathrm{n}$. $\mathrm{m}$. The fountain is in a broad stream located approximately 100 meters from the forest path that leads from the village of Sentice to a village by the Svratka River. The site is marked with a wooden sign. The fountain was renovated in 2010. The fountain is located approximately $2.5 \mathrm{~km}$ north of Veverské Bítýška.

The adjusted spring is collected in headwater reservoirs, which is built of concrete and covered with stones. The whole design of the well is a combination of: natural stone, concrete, wood, and asphalt roofing shingles. From the construction of drainage pipe exits, the downstream floor is not regulated. The water drain is $2 \mathrm{~m}$ from the well concentrated into a furrow. Then, the water spreads over the surface. Besides the well is a wooden bench. There are many signposts on the road with directions to the accessible spring.

\subsection{Measurement results}

The mapped spring in the woods of Brno were monitored for one year. Measurement of the parameters of the water was begun in May 2014. Each month, the following water parameters were monitored: water temperature, $\mathrm{pH}$, and the oxygen content of the spring. Twice a year, the samples were taken for a complex analysis at a laboratory where the following were investigated: $\mathrm{pH}$, conductivity, KNK4,5, chlorides, ammonium ions, nitrate, nitrite, C.O.D. (Mn), turbidity, color, calcium + magnesium, iron, colonies of coliform bacteria, between $36^{\circ} \mathrm{C}$ and $22{ }^{\circ} \mathrm{C}$. Values of air temperature and rainfall, from which the dependence of the spring on the environment, were examined. The values obtained from laboratory analyses were then compared with the values in accordance with Decree no. 252/2004 Coll., which lays down the hygienic requirements for drinking water. In May 2014, a total of 3 spring and a non flow Olšová spring, spring U Širokého proudu and V Hájku spring. In June water was removed from the water reservoirs, to obtain values of $\mathrm{pH}$, temperature and dissolved oxygen. In the following months, all the wells flowed.

The temperature of water in the springs was measured at regular monthly intervals. The U Sovy spring showed the highest temperature differences in the summer and winter. The Brčálka spring showed the smallest differences.

The measured $\mathrm{pH}$ values shows, alder spring each month shows values less than 6.5 , which is the lowest limit of the $\mathrm{pH}$ of drinking water, according to decree no. 252/2004 Coll. The U Sovy spring has the highest values of $\mathrm{pH}$, which always exceeded the value of pH 7. PH values show little fluctuation throughout the year. The Brčálka and U Šrokého proudu springs are on the border with 6.5. The value defined by Decree no. 252/2004 Coll. Drinking water is from 6.5 to 9.5 .

Most water in the U Sovy contains dissolved oxygen. The value in February 2015 is above $14 \mathrm{mg} / \mathrm{l}$. The U Šrokého proudu spring contains the least amount of dissolved oxygen. The oxygen content depends mainly on the temperature and pressure of the atmosphere. In the summer months (from June 2014 to August 2014) values are substantially lower than in the autumn and winter months. 


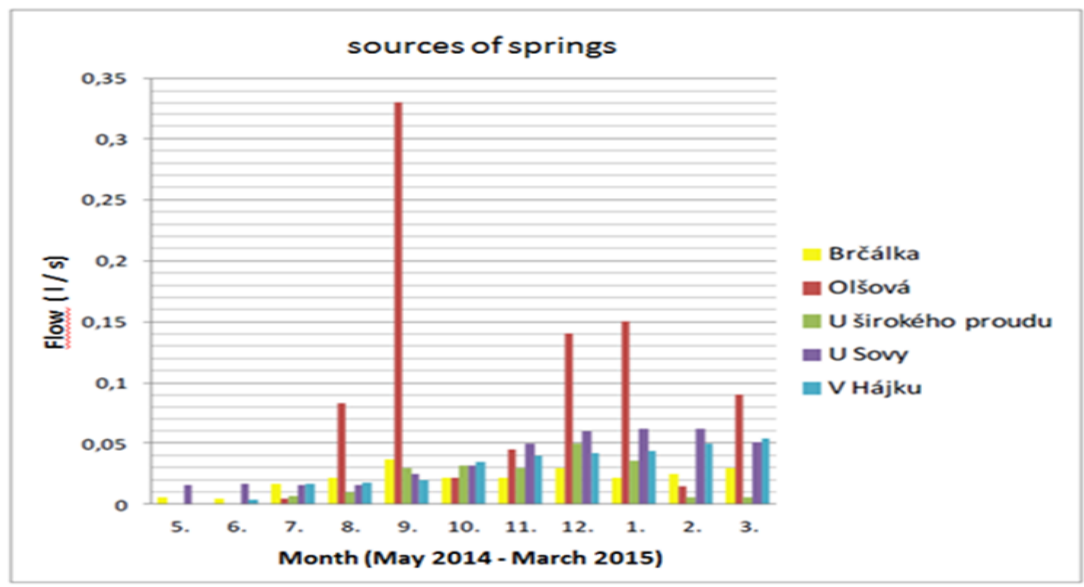

Fig. 1. strength of the sources of springs.

Fig. 1 shows the strength of springs in $1 / \mathrm{s}$ in each month. The Olšová spring showed the highest flow volatility, when the flow rate in September amounted to $0.33 \mathrm{l} / \mathrm{s}$, the following October, 0.022 1/s. The Hájku Brčálka, U Sovy and U Širokého proudu springs had a balanced flow. In most wells the strengh of the source springs moved to $0,05 \mathrm{l} / \mathrm{s}$. In addition, the field measurements were evaluated by laboratory analyses, which were conducted in October 2014 and February 2015. The analyses were performed in the laboratory at the Brněnské vodárny a kanalizace, a.s. company.

Regarding conductivity in the water in October and February, the values measured in October 2014 are higher than the values measured in February 2015. The highest conductivity value was for the V Hájku spring, where conductivity in both months is more than $70 \mathrm{mS} / \mathrm{m}$. However, the value does not exceed the maximum allowable conductivity according to Decree no. 252/2004 Coll., which is $125 \mathrm{mS} / \mathrm{m}$. Therefore, all springs conform to the provisions. The lowest conductivity value was measured in the Olšová spring.

The analysis results KNK4,5. In natural waters, this value shows the amount of hydrogencarbonates contained in the water. This analysis illustrates the alkalinity of water, which means the ability of water to neutralize acid reacting substances. Water samples of an individual spring do not exceed $5 \mathrm{mmol} / \mathrm{l}$. The lowest value was measured at Olšová and Brčálka springs. The highest values were in the U Širokého proudu, V Hájku and U Sovy springs. This value corresponds to the total content of HCO3- in the water. The neutralizing capacity is important in determining the course of the biological processes in natural waters.; in particular, the self-purification capacity of water. Value neutralizing capacities are not limited, Decree no. 252/2004 Coll.

The highest chloride content was detected in the V Hájku spring, wherethe value was around $25 \mathrm{mg} / \mathrm{l}$ in the two months. An analysis of the V Hájku spring for individual months show greater differences than the other springs. The limit value according to Decree no. 252/2004 Coll is $100 \mathrm{mg} / \mathrm{l}$. All springs must comply with this value for drinking water.

The highest nitrate content includes the V Hájku spring, which is almost double the decree no. 252/2004 Coll., Which sets the maximum limit at $50 \mathrm{mg} / \mathrm{l}$. A higher content of nitrates in the V Hájku spring was measured in February. The other springs complied with this decree. The U Sovy spring also had an increased nitrate content. The least nitrates were found in the Olšová and Brčálka spring where the measured values were below $10 \mathrm{mg} / \mathrm{l}$. The occurrence of nitrate significantly reduces the quality of water for drinking purposes.

Nitrites are in all cases included in tiny amounts of less than $0.012 \mathrm{mg} / \mathrm{l}$. The maximum limit value for nitrates in accordance with Decree no. 252/2004 Coll. is $0.50 \mathrm{mg} / \mathrm{l}$. There are also values of ammonium ions. The Olšová spring contained the highest amount of 
ammonium ions. The limit value according to Decree no. 252/2004 Coll. Is $0.50 \mathrm{mg} / \mathrm{l}$. The other spring have a small amount of ammonium ions.

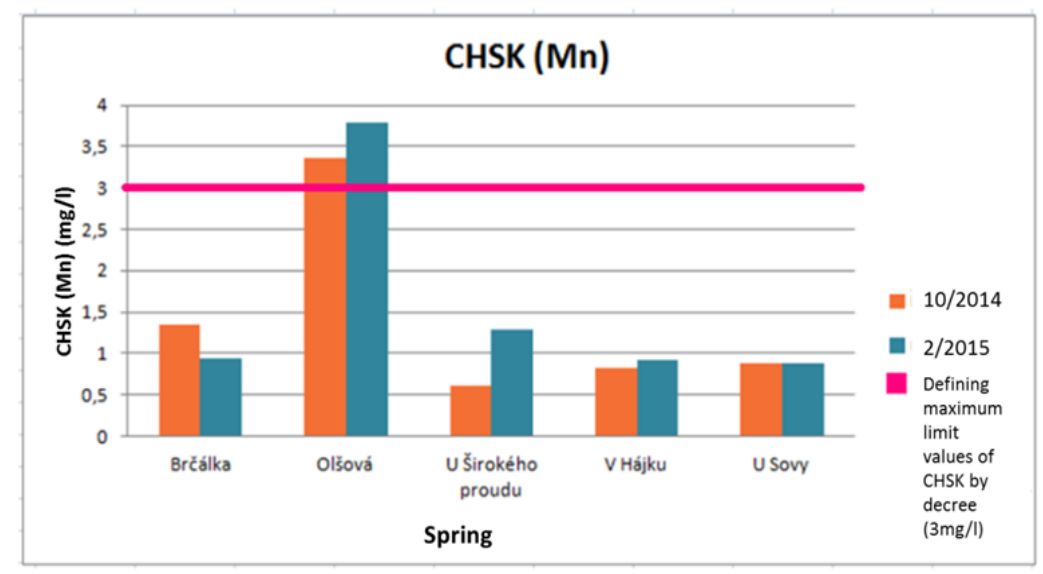

Fig. 2. Content of C.O.D. (Mn) in water in an individual spring.

Fig. 2 shows the amount of C.O.D. (Mn) contained in an individual spring. The Olšová spring showed a higher value than allowed by Decree no. 252/2004 Coll.. In most cases, except for Brčálky spring, the C.O.D. (Mn) is higher than in February October. U Šrokého proudu spring had the biggest difference in the amount of C.O.D. (Mn) in the monitored month.

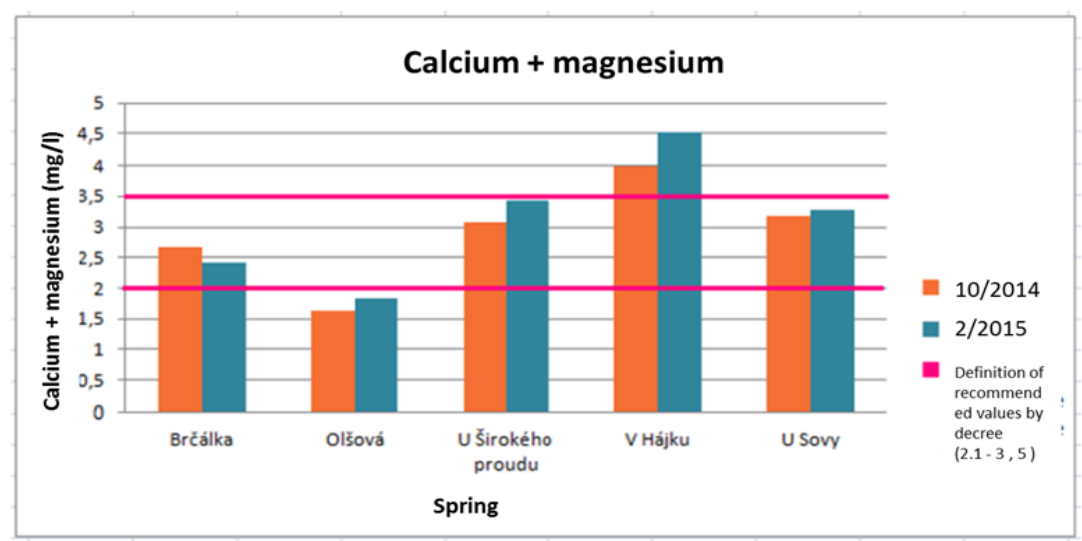

Fig. 3. The content of calcium and magnesium in the water in individual spring.

Fig. 3 shows the amount of calcium and magnesium in the water in an individual spring in October and February. Almost all, except for the Brčálka spring, the amount of calcium and magnesium was higher in February. The recommended values according to Decree no. 252/2004 Coll are also shown, which are set in the range 2.0-3.5 mg/l. V Hájku spring exceeds the recommended range, while the Olšová spring does not reach this range. The range for the Brčálka, U Sovy and u Šrokého proudu spring ranges is located in the recommended values.

In the February analysis iron less than $0.03 \mathrm{mg} / \mathrm{l}$ was contained in all the springs. In the October analysis, except for the Brčálka spring, the other springs contained higher amounts of iron. The highest value was measured in the U Sovy spring, which reached a value of $0.07 \mathrm{mg} / \mathrm{l}$. The limit value established by Decree no. 252/2004 Coll. Is $0.20 \mathrm{mg} / \mathrm{l}$. This value was not reached by any of the mapped springs. 
Amount monitored of coliform bacteria in October and February in individual spring. In February, no coliform bacteria were present in any of the monitored springs. The highest number of coliform bacteria was evaluated in October at the V Hájku spring where the value climbed to $20 \mathrm{cfu} / 100 \mathrm{ml}$. In October, the Olšová and U Sovy spring analysis contained $7 \mathrm{cfu} / 100 \mathrm{ml}$; the limit value according to Decree no. 252/2004 Coll. is set to 0 $\mathrm{cfu} / 100 \mathrm{ml}$ The Brčálka and U Šrokého proudu springs reached this limit in the two months of spring. These bacteria indicate fecal contamination and a poor protection of water resources.

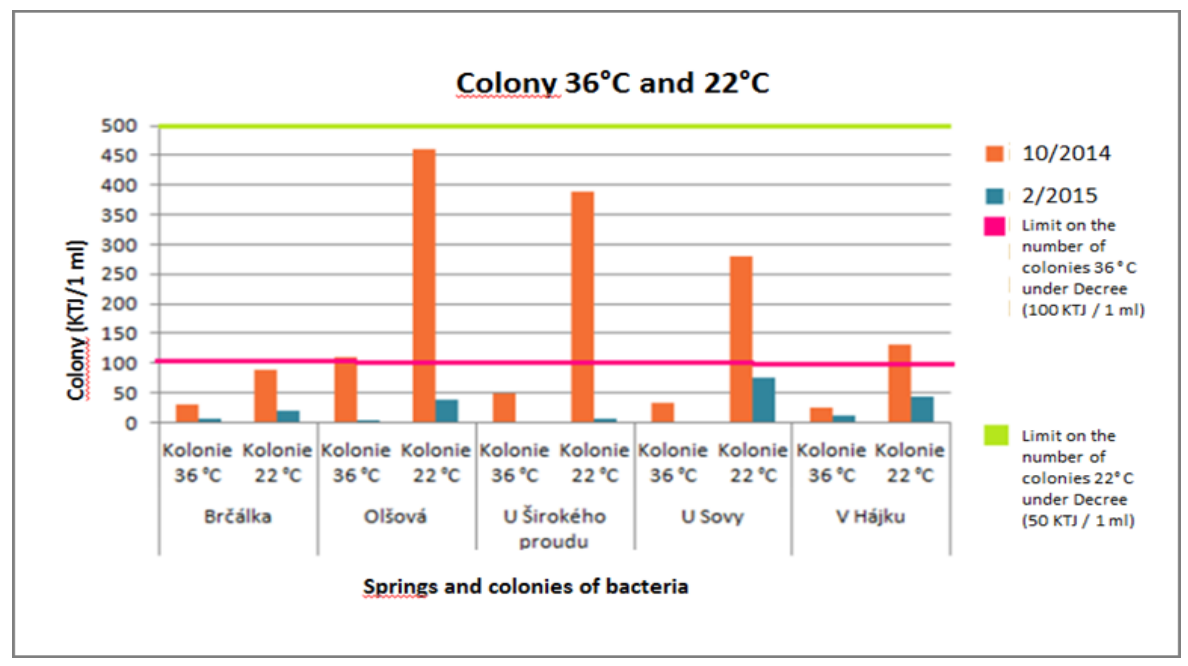

Fig. 4. number of colonies of $36^{\circ} \mathrm{C}$ and $22^{\circ} \mathrm{C}$ the colonies in springs.

Fig. 4 shows the amount of bacteria in springs in February and October. Colonies $22{ }^{\circ} \mathrm{C}$ do not exceed the limit value according to Decree no. 252/2004 Coll. Outside of spring. The Colonies limit value of $36^{\circ} \mathrm{C}$ was exceeded at Olšová spring in October analyses. The highest number of colonies of $22{ }^{\circ} \mathrm{C}$ was evaluated in the October analysis at the Olšová spring; which was also was found to be higher at the U Šrokého proudu spring. In the A February analysis of the number of colonies was considerably less than in October. The limit values according to Decree no. 252/2004 Coll. colonies are $22{ }^{\circ} \mathrm{C}$ equal to 500 $\mathrm{CFU} / \mathrm{ml}$ and 1 to $36{ }^{\circ} \mathrm{C}$, colonies of $100 \mathrm{CFU} / 1 \mathrm{ml}$.

\section{Conclusion}

The article concerns wells in the landscape. The area of interest was the northern part of the Brno-venkov district near Lelekovice and Veverské Bítýška. The fountains are located in the woods of Brno and cared for by the Lesy města Brna, a.s. company. The following springs were monitored: Brčálka, Olšová, U širokého proudu, U Sovy and V Hájku. The aim was to monitor selected springs at regular monthly intervals to measure the basic parameters of the water. Each month, the following water parameters were measured: water temperature, $\mathrm{pH}$, dissolved oxygen and strength of source. Twice a year, laboratory analyses were done as required by the contracting authority, and the results then compared with Decree no. 252/2004 Coll., establishing the hygienic requirements for drinking water. They were also graphically evaluated according to the strength of the source of monthly rainfall and dependent temperature of water at an ambient temperature. The results of the regular monthly measurements and laboratory measurements, conducted in October 2014 and February 2015, were processed in graphs and compared. The regular measurements of 
water parameters were evaluated. In nearly all the wells, the $\mathrm{pH}$ ranges from $6.5-7$. The U Sovy spring is compared with other higher $\mathrm{pH}$ range 7-7.5. The Olšová spring has the lowest $\mathrm{pH}$, which was mostly below 6 . The water temperature at none of the observed springs did not fall below $5^{\circ} \mathrm{C}$ in the winter. The amount of dissolved oxygen in the water depends on the temperature and atmospheric pressure. The most oxygen was measured in the U Sovy spring. The strength of the source of the monitored wells was diverse. The Olšová spring had the most volatile flows (largely dependent on rainfall). The other springs had relatively stable flows, which were higher from October 2014 to January 2015. In May and June 2014, these were the non-draining springs: Olšová, U širokého proudy, and V Hájku.

Laboratory analyses were carried out in October 2014 and February 2015. The results showed, that in the Brčálka and Uširokého proudu springs is high-quality drinking water. The resulting values were compared with Decree no. 252/2004 Coll. and no values exceeded the limit allowed. In the October analysis, the U Sovy spring contained increased amounts of coliform bacteria, and therefore did not comply with the qualities of drinking water. In February, it met the parameters of the spring Decree no. 252/2004 Coll.

From the results of the analyses it appears The Olšová and V Hájku springs did not comply with this decree. The Olšová spring exceeded the limit value of $\mathrm{pH}, \mathrm{COD}(\mathrm{Mn})$ and October 2014 values for coliforms colonies and $36^{\circ} \mathrm{C}$. In the V Hájku spring did not have the maximum limit of nitrates. Analysis showed that the water comprises in October 2014 $89,1 \mathrm{mg} / 1$ and in February $201593 \mathrm{mg} / 1$. The value allowed for drinking water is 50 $\mathrm{mg} / \mathrm{l}$. The values were found to exceed the limit values by double. The elevated nitrate levels are probably the result of improper nitrate fertilization on nearby agricultural lands. This could improve the management of suitable land, for example: grassing and using alternative fertilizers.

The article contains partial results of the research project "Minimizing losses of forest and agricultural land due to erosion and abrasion processes in the landscape" reg. No. LDF_PSV_2016002, funded by IGA FFWT MENDELU Brno.

\section{References}

1. G. Markovič, Z. Vranayová; Vsakovanie ako spôsob nakladania so zrážkovými vodami z povrchového odtoku 1. vyd. - Košice : TU 137 p., ISBN 978-80-553-1541-6 (2013)

2. B. Hruška, S. Jelínek; Lesnická geologie, Brno: Mendelova zemědělská a lesnická univerzita, 197 p., ISBN 80-7157-321-2 (1998)

3. A. Ondrůjová, V. Hubačíková; Monitoring of phosphorus in selected profiles of the Veverka stream, 20th International PhD Students Conference Location: Mendel Univ, Fac Agron, Pages: 336-340, MENDELNET (2013)

4. V. O. Harbulakova, M. Zelenakova, M. Rysulova, et al. Evaluation of Ecological Flow and Concentrations of Pollutants in Selected River Basin in Eastern Slovakia, Conference: 2nd International Conference on Efficient and Sustainable Water Systems Management toward Worth Living Development (EWaS) Procedia Engineering, 162 ,98-105 (2016)

5. J. Drápalová, R. Pecháček., O. Skácelová; Studánky v okolí Babího lomu. 1. vydání, Brno: ČSOP, 10 p., (2002) 